\title{
KARAKTERISASI SIFAT TARIK KOMPOSIT HIBRID KARBON/ABAKA/PMMA SEBAGAI BAHAN ALTERNATIF PROSTHESIS
}

\author{
Beni Firiya \\ Fakultas Teknik, Program Studi Teknik Mesin \\ Universitas Muhammadiyah Yogyakarta \\ Email: benifiri36@gmail.com \\ Marizal \\ Fakultas Teknik, Program Studi Teknik Mesin \\ Universitas Muhammadiyah Yogyakarta \\ Email: marizalaja52@gmail.com \\ Bagas Mulya Waskitho \\ Fakultas Teknik, Program Studi Teknik Mesin \\ Universitas Muhammadiyah Yogyakarta \\ Email: bagasmulya29@gmail.com \\ Harini Sosiati* \\ Fakultas Teknik, Program Studi Teknik Mesin \\ Universitas Muhammadiyah Yogyakarta \\ Email:*hsosiati@ft.umy.ac.id
}

\begin{abstract}
ABSTRAK
Serat karbon dan abaka sebagai penguat komposit hybrid polymethyl methacrylate (PMMA) adalah salah satu bahan fungsional. Komposit ini akan bermanfaat untuk bahan alternatif prosthesis karena kekuatan mekaniknya yang relatif tinggi, ringan, dan biokompatibel dengan jaringan manusia. Pada penelitian ini komposit karbon/abaka/PMMA difabrikasi menggunakan metode hand-lay-up dan cold press molding dengan tekanan 2,185 MPa selama 60 menit, dengan tujuan untuk mengkarakterisasi sifat tarik komposit dengan variasi perbandingan serat karbon dan abaka 1:2, 1:1 dan 2:1, serta fraksi volume serat $20 \%$. Sebelum fabrikasi komposit, serat karbon diberi perlakuan dengan direndam dalam nitrogen cair (liquid $\mathrm{N}_{2}$ ) selama kurang lebih 10 menit. Sedangkan serat abaka diberi perlakuan alkalisasi dalam larutan $6 \% \mathrm{NaOH}$ pada suhu kamar selama 36 jam. Sifat kimia serat abaka sebelum dan sesudah alkalisasi dianalisis dengan Fourier transformed infrared (FTIR) spectroscopy. Uji tarik dilakukan pada semua spesimen komposit mengacu pada ASTM D638. Hasil uji tarik disimulasikan dengan perangkat lunak Autodesk Inventor 2019 dan Nastran-In CAD 2019 untuk mengetahui kelayakan bahan untuk aplikasi prosthesis. Nilai kuat tarik dan modulus elastisitas tertinggi dari hasil penelitian ini ditunjukan pada komposit dengan perbandingan serat karbon dan abaka 2:1 masing-masing yaitu 105,71 $\mathrm{MPa}$ dan 5,24 GPa. Sedangkan hasil simulasi menyatakan bahwa material komposit karbon/abaka/PMMA dapat direkomendasikan sebagai bahan alternatif prosthesis.
\end{abstract}

Kata kunci: serat abaka, serat karbon, PMMA, komposit hibrid, sifat tarik.

\section{ABSTRACT}

Carbon and abaca fibers reinforced polymethyl methacrylate (PMMA) hybrid composite is one of the functional materials. This composite would be useful for an alternative prosthesis 
material due to its comparatively high mechanical strength, lightweight, and biocompatible with human tissues. In this study carbon/abaca/PMMA composites have been fabricated using handlay-up and cold press molding methods with a pressure of $2.185 \mathrm{MPa}$ for 60 minutes, with the aim to characterize the tensile properties of the composite with carbon fiber into abaca ratios of 1: 2 , 1: 1 and 2: 1, and 20\% fiber volume fraction. Before composite fabrication, carbon fibers were treated by soaking it in liquid nitrogen (liquid $N_{2}$ ) for approximately 10 minutes, While the abaca fibers were alkalized in $6 \% \mathrm{NaOH}$ at room temperature for 36 hours. The chemical properties of abaca fibers before and after alkalization were analyzed by Fourier transformed infrared (FTIR) spectroscopy. Tensile tests were carried out on all composite specimens according to ASTM D638. The tensile test results were simulated with Autodesk Inventor 2019 and Nastran In-CAD 2019 software to determine the suitability of the materials for prosthesis applications. The composite with a ratio of carbon fiber into abaca 2: 1 showed the highest tensile strength and modulus of elasticity of $105.71 \mathrm{MPa}$ and $5.24 \mathrm{GPa}$, respectively. The simulation results stated that carbon/abaca/PMMA composite materials would be potential as an alternative prosthesis material.

Keywords: abaca fiber, carbon fiber, PMMA, hybrid composite, tensile properties

\section{PENDAHULUAN}

Serat karbon, serat abaka dan polymethylmetacrylate (PMMA) adalah bahan penyusun komposit yang fungsional, karena memiliki sifat-sifat yang kompatibel dengan persyaratan bahan perangkat biomedis $[1,2]$. Serat karbon memiliki sifat mekanis yang tinggi dan pada umumnya bersifat hidrofobik tergantung dari oksida yang ada pada permukaan serat karbon [3]. Serat abaka merupakan salah satu serat alam yang tersedia melimpah di negara beriklim tropis seperti Indonesia. Serat abaka juga memiliki sifat tarik relatif tinggi, ringan, murah dan biokompatibel dengan jaringan tubuh manusia. Namun, sifat serat abaka seperti serat alam pada umumnya memiliki kelemahan yaitu resistensinya rendah dan mudah terdegradasi.

Selain itu sifat hidrofilik serat alam (abaka) menjadi masalah utama dalam pembuatan komposit serat alam, dikarenakan memiliki sifat hidrofilik, yang tidak kompatibel dengan sifat hidrofobik yang dimiliki oleh bahan matriks dalam hal ini PMMA, sehingga dapat mengakibatkan lemahnya ikatan antarmuka serat dan matriks. Hal ini akan menurunkan sifat mekanis komposit serat alam. Oleh karena itu, metode paling mudah untuk meningkatkan sifat mekanis komposit adalah dengan memberi perlakuan alkalisasi pada permukaan serat [4]. PMMA adalah bahan polimer sintetis non-crystalline yang umum digunakan dibidang orthopedic sebagai bone cement untuk implant imbuhan dan merombak tulang yang hilang.

Beberapa penelitian komposit serat alam untuk aplikasi prosthesis telah dilaporkan, diantaranya yaitu komposit serat bamboo dengan matriks epoxy [5], komposit serat rotan/epoxy [6], komposit serat rami/epoxy [7], komposit serat nanas/epoxy dan komposit hibrid serat nanas/serat glass/poliester [8]. Pada penelitian tersebut telah dilakukan uji tarik, impak dan bending dengan variasi fraksi volume serat. Berdasarkan nilai sifat mekanis komposit dari beberapa hasil penelitian tersebut disimpulkan bahwa berbagai jenis material komposit tersebut berpotensi untuk dikembangkan sebagai bahan pembuatan prosthesis.

Selain itu, penelitian yang terkait komposit hibrid serat alam dan serat sintetis dengan matriks PMMA sebagai perangkat biomedis telah dilaporkan oleh [9]. Komposit dibuat dengan variasi perbandingan serat sisal dan karbon 1:1, 2:1, 1:2 dan fraksi volume serat 20\%. Hasil kuat tarik dan modulus elastisitas optimum terjadi pada variasi serat sisal dan karbon 1:2 masing-masing yaitu 54,21 $\mathrm{MPa}$ dan 1,42 GPa. Kuat tarik yang dihasilkan penelitian ini lebih rendah dibandingkan dengan material komposit dengan matriks epoxy [5]-[8]. Namun modulus elastisitas material komposit sisal/karbon/PMMA yang dihasilkan jauh lebih rendah dari pada material komposit bermatriks epoxy, cenderung memiliki kegetasan rendah.

2 Karakterisasi Sifat Tarik... (Beni Firiya, Marizal, Bagus Mulya Waskitho, Harini Sosiati) 
Oleh karena itu pada penelitian ini dibuat material komposit hibrid serat karbon dan abaka sebagai penguat/pengisi matriks polimer PMMA untuk dikembangkan sebagai bahan alternatif prosthesis dan dibandingkan sifat mekanisnya dengan material komposit yang telah dilaporkan. Tujuan dari penelitian ini adalah untuk mengetahui pengaruh variasi rasio serat karbon/abaka terhadap sifat tarik komposit hibrid karbon/abaka/PMMA, dan kelayakan bahan komposit tersebut sebagai bahan alternatif perangkat biomedis (prosthesis) dengan mensimulasikan menggunakan aplikasi perangkat lunak yaitu Autodesk Inventor 2019 dan Nastran-In CAD 2019.

\section{METODE PENELITIAN}

Bahan utama yang digunakan pada penelitian ini adalah serat abaka, serat karbon dan PMMA. Serat abaka dibeli dari Balai Penelitian Tanaman Pemanis dan Serat (Balittas), Malang, Jawa Timur. Serat karbon dengan kuat tarik dan modulus masing-masing 4,9 GPa dan $250 \mathrm{GPa}$ dibeli di Hobbyrover, China. Sedangkan PMMA (ISO 1567 Type II Class I) diberi di Toko Dental Jaya, Indonesia.

Pertama serat abaka dicuci bersih dengan air mengalir dan dikeringkan didalam oven pada suhu kurang lebih $100^{\circ} \mathrm{C}$ selama 30 menit. Kemudian serat abaka dialkalisasi dalam larutan $6 \%$ $\mathrm{NaOH}$ pada suhu ruangan selama 36 jam [4] dan dinetralkan dengan larutan 1\% asam asetat. Untuk perlakuan terhadap serat karbon dilakukan dengan perendaman serat karbon dalam nitrogen cair (liquid $\mathrm{N}_{2}$ ) selama 10 menit [10].

Setelah serat karbon dan abaka diberi perlakuan, selanjutnya dipotong masing-masing sepanjang $10 \mathrm{~mm}$ dan $6 \mathrm{~mm}$ dan disiapkan untuk fabrikasi komposit dengan fraksi volume serat (abaka dan karbon) 20\%. Sedangkan serat karbon dan serat abaka divariasi dengan perbandingan 1:2, 1:1 dan 2:1. Proses fabrikasi komposit dilakukan menggunakan cold press molding dan metode hand lay-up dengan tekanan 2,185 MPa selama 60 menit. Semua spesimen komposit yang dihasilkan, diuji tarik dengan mengacu pada ASTM D638. Selanjutnya scanning electron microscopy (SEM) dilakukan untuk mengkarakterisasi permukaan patahan hasil uji tarik dan menganalisis perubahan nilai sifat tarik spesimen komposit. Pada penelitian ini, serat abaka sebelum dan sesudah alkalisasi juga diuji dengan fourier transformed infrared (FTIR) spectroscopy untuk mengetahui perubahan komposisi kimia serat secara kualitatif. Selain itu, untuk mengetahui apakah produk komposit yang dihasilkan dari penelitian ini dapat direkomendasikan sebagai bahan alternatif perangkat biomedis (prosthesis), maka dilakukan simulasi terhadap nilai sifat tarik komposit menggunakan perangkat lunak Autodesk Inventor 2019 dan Nastran in CAD 2019.

\section{HASIL DAN PEMBAHASAN}

\subsection{Karakteristik serat abaka}

Hasil uji serat dengan FTIR (gambar 1) menunjukkan perbedaan yang jelas antara serat abaka sebelum dan sesudah dialkalisasi. Puncak selulosa terdapat pada serat yang tidak diberi perlakuan, bersama dengan puncak tambahan pada gelombang $17281 / \mathrm{cm}$ dan $12421 / \mathrm{cm}$ yang masingmasing menunjukkan gugus $\mathrm{C}=\mathrm{O}$ dan $\mathrm{C}-\mathrm{O}$, puncak pada $17281 / \mathrm{cm}$ adalah karakteristik untuk peregangan karbonil kelompok karbosilat di hemiselulosa [11]. Setelah alkalisasi puncak tersebut tidak teridentifikasi. Hal ini menunjukkan bahwa hemiselulosa terlarut secara keseluruhan dalam larutan alkali [4]. Puncak pada posisi 1242 1/cm menunjukkan gugus C-O dari kelompok asetil pada lignin. Setelah alkalisasi puncak tersebut terlihat semakin tidak, mengindikasikan jumlah lignin yang berkurang akibat alkalisasi. 


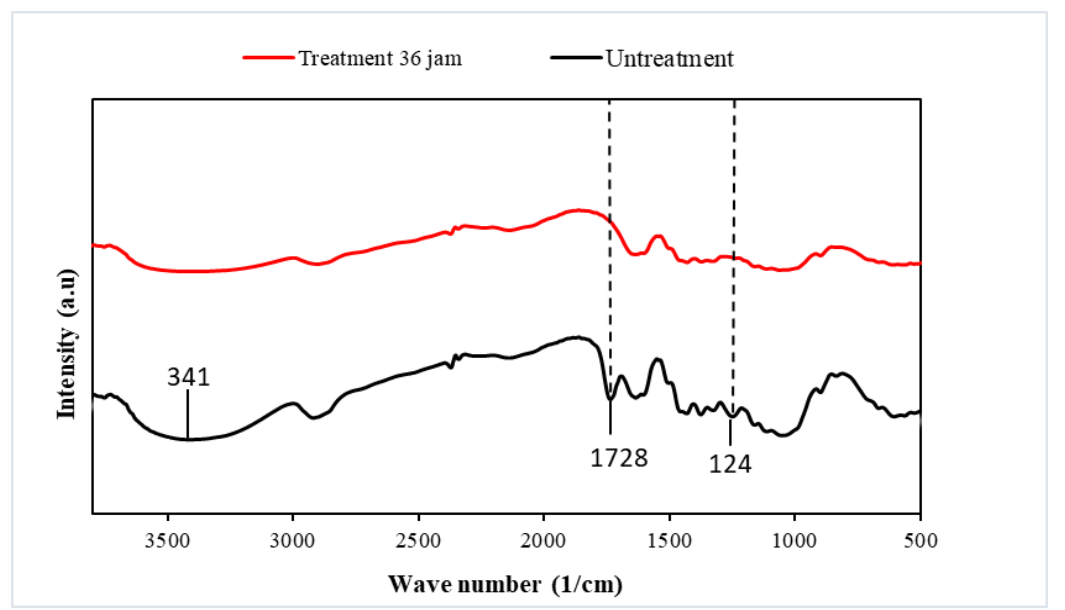

Gambar 1. Spektra FTIR dari serat abaka.

Foto SEM serat abaka (gambar 2) juga menunjukkan adanya perbedaan morfologi antara serat sebelum (gambar 2a) dan setelah alkalisasi (gambar 2b). Sebelum alkalisasi serat selulosa tergabung/terikat oleh lignin menjadi satu bundel serat. Akan tetapi, setelah alkalisasi selama 36 jam terlihat bahwa sebagian serat selulosa terurai dari ikatannya (terfibrilasi) akibat terlarutnya sebagian lignin dalam $\mathrm{NaOH}$ (gambar 2b). Dalam hal ini karakteristik serat abaka hasil uji SEM dan FTIR menunjukkan hasil yang sesuai.
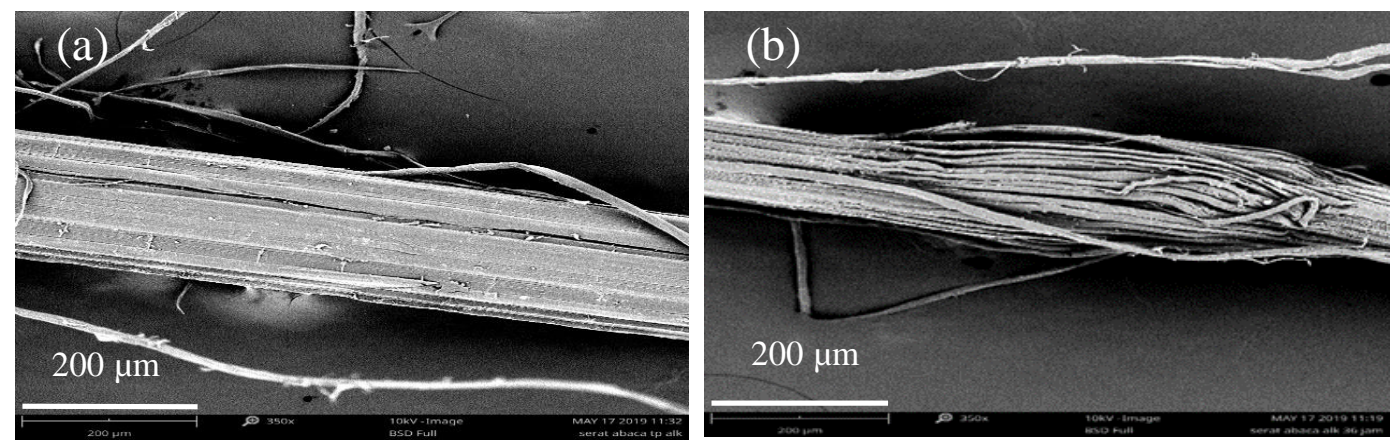

Gambar 2. Foto SEM (a) serat abaka sebelum dan (b) serat abaka sesudah alkalisasi

\subsection{Sifat tarik komposit hibrid karbon/abaka/PMMA}

Hasil uji tarik komposit hibrid karbon/abaka/PMMA dengan variasi rasio serat karbon dan serat abaka (gambar 3) memperlihatkan bahwa semakin tinggi kandungan serat karbon kuat tarik dan modulus komposit meningkat dengan nilai tertinggi ditunjukkan pada komposit dengan perbandingan serat karbon dan abaka 2:1 yaitu masing-masing 105,71 $\mathrm{MPa}$ dan 5,24 $\mathrm{GPa}$. Perubahan nilai kuat tarik dengan perbedaan rasio serat karbon dan abaka dapat dijelaskan dari hasil analisis uji SEM yang ditunjukkan pada gambar 4.

Nilai sifat tarik yang dihasilkan dari penelitian ini dibandingkan dengan hasil penelitian sebelumnya, secara signifikan menunjukkan nilai yang lebih tinggi. Kuat tarik dan modulus komposit serat bamboo/epoxy, rotan/epoxy, rami/epoxy, serat nanas/epoxy masing-masing menunjukkan nilai sebesar $81 \mathrm{MPa}$ dan 8,9 GPa [5], $65 \mathrm{MPa}$ dan 8,6 GPa [6], 86 MPa dan 9,5 GPa [7], 77,4 MPa dan 7,9 GPa [8], dan [9] menghasilkan kuat tarik sebesar 54,21 MPa dan modulus elastisitas 1,42 GPa. 


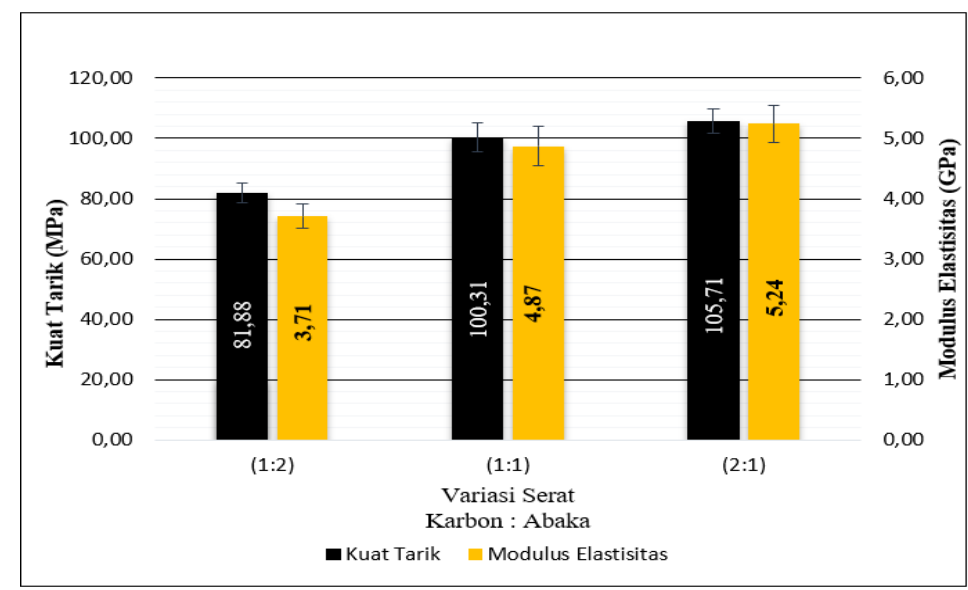

Gambar 3. Kuat tarik dan modulus elastisitas.

\subsection{Analisis SEM komposit hibrid karbon/abaka/PMMA}

Gambar 4 menunjukkan foto SEM permukaan patahan hasil uji tarik komposit karbon/abaka/PMMA dengan perbedaan rasio karbon dan abaka. Foto SEM pada gambar 4a, 4b dan 4c memperlihatkan morfologi yang hampir sama. Secara keseluruhan ikatan serat (karbon dan abaka) dan matriks PMMA relatif terikat dengan baik yaitu, namun distribusi serat karbon dalam matrik tidak terdispersi secara homogen, seperti terlihat pada gambar 4a. Selain itu fiber pull-out masih teridentifikasi diseluruh area spesimen. Hal ini dapat dijelaskan bahwa ada kemungkinan pada saat fabrikasi komposit, pencampuran serat dan matriks yang dilakukan secara manual kurang homogen, sehingga ada sebagian permukaan serat yang tidak terbasahi oleh matriks. Akibatnya tidak ada transfer stress dari matriks kearah serat, dan pada saat dilakukan uji tarik, serat tidak dapat menahan beban, sehingga mudah terlepas dan menurunkan kekuatan mekanis komposit.

Dengan semakin banyak kandungan serat karbon dibanding serat abaka, semakin tinggi nilai kuat tarik komposit (gambar 3), hal ini dapat dijelaskan bahwa dengan semakin sedikit jumlah serat abakanya, maka kemungkinan terjadinya fiber pull-out juga semakin berkurang. Kecenderungan ini ditunjukkan pada gambar 4c. Selain itu, karena sifat tarik serat karbon jauh lebih tinggi dari pada serat abaka, maka dengan banyaknya kandungan serat karbon meningkatkan sifat tarik komposit yang terkait.
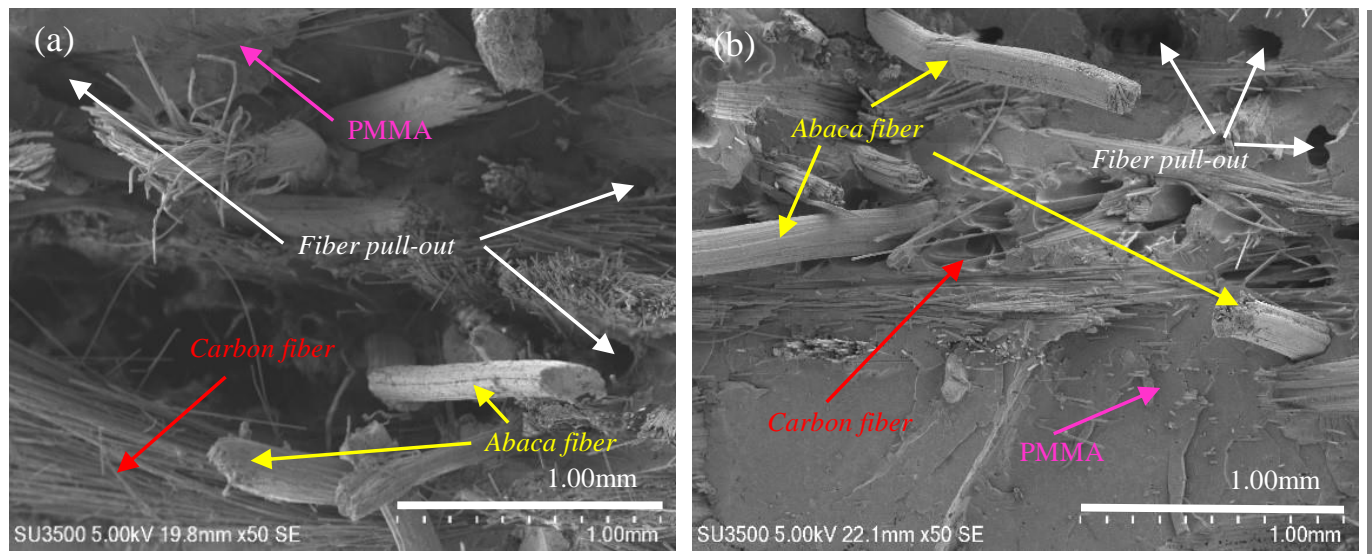


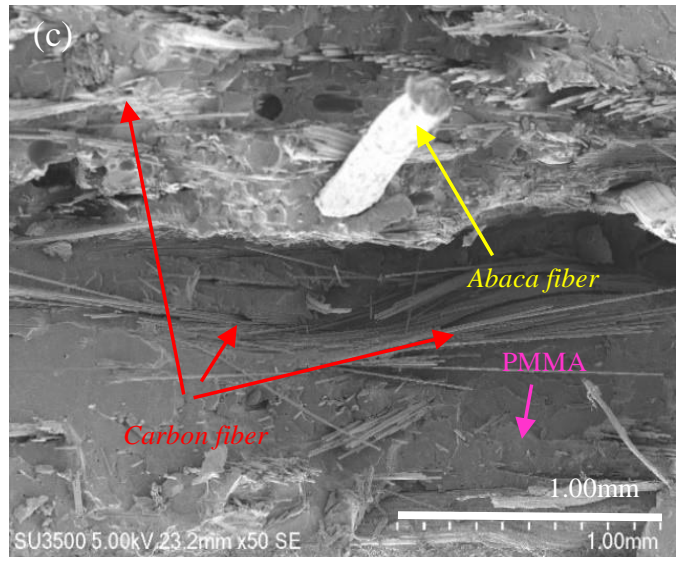

\section{Gambar 4 (a) Foto SEM permukaan patahan komposit hibrid karbon/abaka/PMMA dengan rasio karbon/abaka yang berbeda. (a) 1:2, (b) 1:1 dan (c) 2:1.}

\subsection{Analisa Simulasi}

Hasil uji tarik komposit hibrid karbon/abaka/PMMA disimulasikan menggunakan aplikasi perangkat lunak Autodesk Inventor 2019 dan Nastran In-CAD 2019 dapat dilihat pada simulasi disain terjadi displacement (pergeseran material) sebesar $1,545 \mathrm{~mm}$ dengan pembebanan yang diberikan pada disain sebesar 676,89 N (gambar 5a).

Hasil displacement pada penelitian ini berada dibawah penelitian [12] sebesar 1 inchi. Kemudian untuk menentukan material komposit hibrid karbon/abaka/PMMA sebagai bahan alternatif prosthesis, maka dilakukan simulasi hasil von misses stress pada disain. Hasil pada simulasi disain yang terlihat pada (gambar 5b) menunjukkan tegangan sebesar 25,074 MPa dan daerah von misses stress dapat dilihat pada gambar $5 \mathrm{c}$.

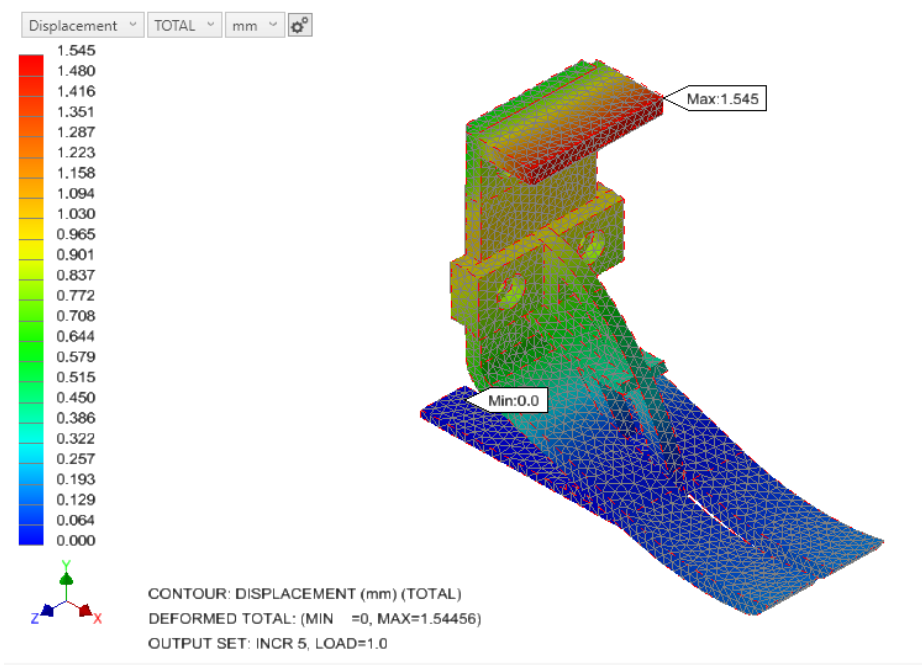

Gambar 5a. Simulasi Desain Displacement.

6 Karakterisasi Sifat Tarik... (Beni Firiya, Marizal, Bagus Mulya Waskitho, Harini Sosiati) 


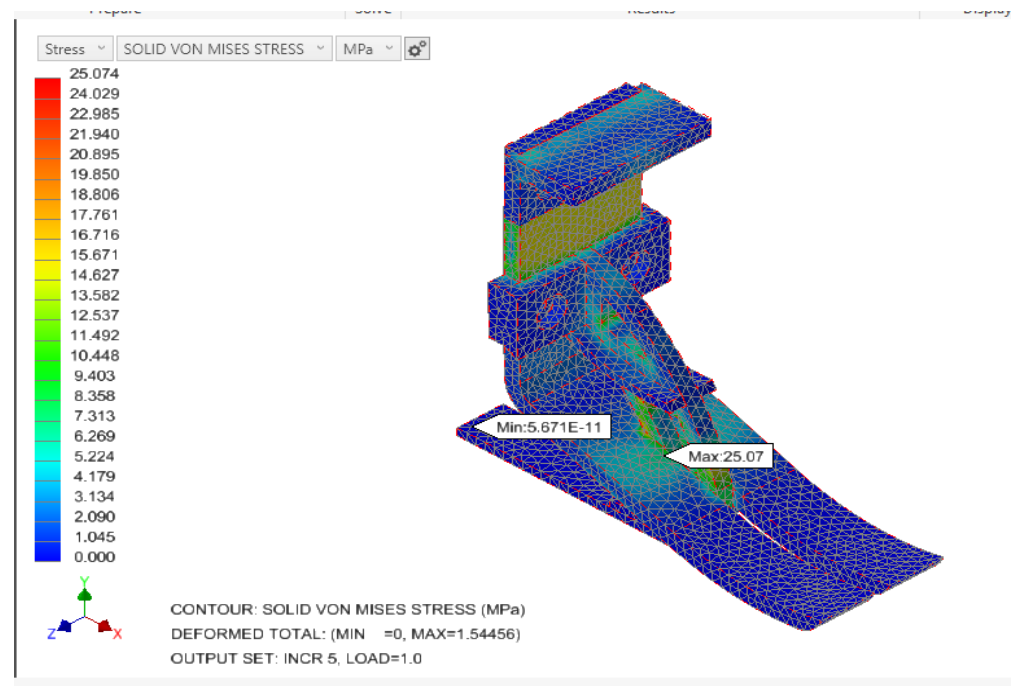

Gambar 5b. Simulasi Disain Von Misses Stress.

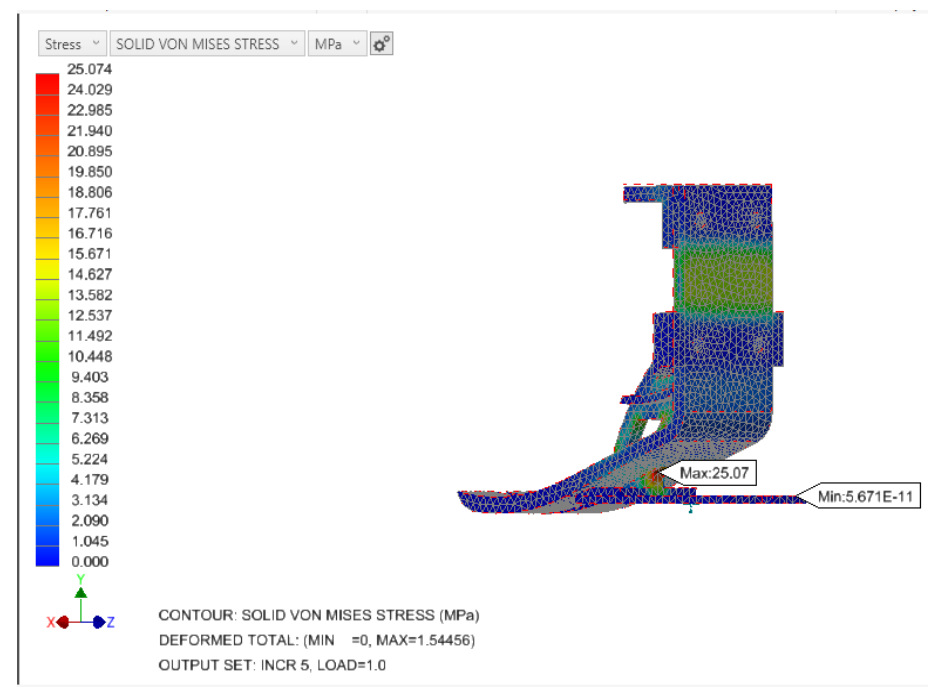

Gambar 5c. Simulasi disain daerah Von Misses Stress.

Dari hasil simulasi dapat disimpulkan bahwa material yang dihasilkan pada penelitian ini dapat direkomendasikan sebagai bahan pembuatan prosthesis dikarenakan hasil von misses stress kurang dari tegangan luluh sebesar $85,6 \mathrm{MPa}$

\section{KESIMPULAN}

Hasil pengujian tarik telah dilakukan pada komposit hybrid karbon/abaka/PMMA untuk mengetahui pengaruh rasio serat karbon/abaka, dan kelayakan komposit sebagai bahan alternatif perangkat biomedis (prosthesis). Dari hasil penelitian ini dapat disimpulkan bahwa komposit 
dengan rasio 2:1 paling tinggi dengan kuat tarik dan modulus masing-masing 105,71 dan 5,24 GPa. Peningkatan sifat komposit disebabkan oleh meningkatnya kandungan serat karbon yang ditunjukkan dengan semakin berkurangnya fraksi volume fiber pull-out. Namun dengan menurunnya kandungan serat karbon atau meningkatnya serat abaka membuat komposit semakin ulet. Hasil karakterisasi sifat tarik komposit dan aplikasi perangkat lunak Autodesk Inventor 2019 dan Nastran In-CAD 2019 menunjukkan bahwa material komposit yang dihasilkan dari penelitian ini dapat direkomendasikan sebagai bahan alternatif pembuatan prosthesis.

\section{DAFTAR PUSTAKA}

[1] Chandramohan, D. \& Marimuthu, K., 2011. Biocomposite Material Based on Biopolymer and Natural Fibers-Contribution as Bone Implant. Int. Journal of Adv. Sci. Appl. Res, 8(2), pp. 009-012.

[2] Namvar, F. et al., 2014. Potensial Use of Plant Fibers and their Composites for Biomedical Application. Cellulosics for biomed use Bio Resources, 9(3), pp. 5688-5706.

[3] Meng, Long-Yue \& Park, Soo-Jin, 2014. Superhydrophobic Carbon-Based Materials: A Review of Synthesis Structure, and Applications. Carbon Letters, 15(2), pp. 89-104.

[4] Sosiati, H. et al., 2019. Characterization of Tensile Propertiesof Alkali-Treated Kenaf/Polypropylene Composites. AIP Publishing, Issue 030113, pp. 1-7.

[5] Irawan, A. P. \& Sukania, I. W., 2012. Tensile end Impact Stength of Bamboo Fiber Reinforced Epoxy Composites as Alternative Materials for Above Knee Prosthetic Socket. International Conference on Sustainable Technology Development, pp. 109-115.

[6] Irawan, A. P. \& Sukania, I. W., 2015. Gait Analysis of Lower Limb Prosthesis with Socket Made from Rattan Fiber Reinforced Epoxy Composite. Asian Online Jurnal of Applied Sciences, 03(01), pp. 8-13.

[7] Irawan, A. P. et al., 2011. Tensile end Flexural Strength of Ramie Fiber Reinforced Epoxy Composites for Socket Prosthesis Application. International Jurnal of Mechanical and Material Engineering, 6(1) pp. 46-50.

[8] Odusote, J. K. \& Oyewo. A. T., 2016. Mechanical Properties of Pineapple Leaf Fiber Reinforced Polymer Composites for Application as A Prosthetic Socket. Journal of Engineering and Technology, 7(1), pp. 125-139.

[9] Sosiati, H., Binangun, Y. A., Utama, A. P. \& Sudarisman, 2019. The Mechanical Properties of Sisal/PMMA and Sisal/Carbon/PMMA Biomedical Composites. To be publish.

[10] Sosiati, H. \& Khalim, A., 2018. Pengaruh Modifikasi Permukaan Serat Karbon terhadap Sifat Bending dan Daya Serap Air Komposit Hibrida Sisal-Karbon/Polivinil Klorida (PVC), Yogyakarta: UMY.

[11] Morán, J.I., Alvarez, V. A., Cyras, V. P., \& Vázquez, A., 2008. Extraction of Cellulose and Preparationof Nanocellulose from Sisal Fibers. Cellulose, 15(1), pp. 149-159.

[12] Zgonis, T., 2012. Surgical Reconstruction of The Diabetic Foot and Ankle. 